\title{
One-Dimensional Creativity: A Marcusean Critique of Work and Play in the Video Game Industry
}

\section{Ergin Bulut}

Westminster Institute for Advanced Studies, London; Koç University, Istanbul, Turkey, ebulut@ku.edu.tr

\begin{abstract}
Creativity is at the heart of the video game industry. Industry professionals, especially those producing blockbuster games for the triple-A market, speak fondly of their creative labour practices, flexible work schedules, and playful workplaces. However, a cursory glance at major triple-A franchises reveals the persistence of sequel game production and a homogeneity in genres and narratives. Herbert Marcuse's critique of one-dimensionality may help to account for this discrepancy between the workers' creative aspirations and the dominant homogeneity in game aesthetics. What I call 'one-dimensional creativity' defines the essence of triple-A game production. In the name of extolling the pleasure principle at work, one-dimensional creativity eliminates the reality principle, but only superficially. One-dimensional creativity gives game developers the opportunity to express themselves, but it is still framed by a particular technological rationality that prioritises profits over experimental art. One-dimensional creativity negates potential forms of creativity that might emerge outside the industry's hit-driven logics. Conceptually, 'one-dimensional creativity' renders visible the instrumentalisation of play and the conservative design principles of triple-A game production - a production that is heavily structured with technological performance, better graphics, interactivity, and speed. Multi-dimensional video game production and aesthetics, the opposite of one-dimensional creativity, is emerging from the DIY game production scene, which is more invested in game narratives and aesthetics outside the dominant logics of one-dimensionality in triple-A game production.
\end{abstract}

Keywords: Herbert Marcuse, one-dimensionality, one-dimensional creativity, video games, digital games, video game industry, immaterial labour, play, political economy.

Acknowledgement: This article was written thanks to the intellectual time provided by the International Research Fellowship programme at the Westminster Institute for Advanced Studies (WIAS), University of Westminster, London, UK. The author would like to thank Benjamin Birkinbine, Paško Bilić and Christian Fuchs for their feedback.

\section{Introduction}

The late 1960 s and early 1970 s constituted a global moment of rebellion. Young people across the world protested against educational institutions, bureaucracy and the working lives of their parents. The reason behind dissent was that the institutional and social life during the 1960s, as they were structured by monopoly capitalism, lacked a rejuvenating spirit. The alienating and deskilling organisation of factory labour and its similar implementations in the office (Braverman 1998/1974) looked unappealing to generations of the 1960s even when hard work was compensated by consumption opportunities beyond the workplace.

Around the same years, the video game industry was coming to existence in an embryonic form. However, the earliest video games such as Tennis for Two or Spacewar were not simply the products of an 'individual creative genius'. Rather, they were 
the historical outcomes of the Cold War. Scientists that were specifically tasked by the US military-industrial complex to undermine the Soviet Union actually created and played these games during moments of boredom at work. It did not take long for the game industry, specifically and primarily Atari, to reterritorialize the participatory experiences of the Cold War's 'computer science nerds' into its capitalist circuits throughout the 1970s (Dyer Witheford and de Peuter 2009).

Prior but temporally close to these countercultural and technologically innovative developments, important advancements were unfolding in the world of critical theory. At the centre stood the New Left's "guru" in the US: Herbert Marcuse (Funke, Lamas and Wolfson 2017, 3). Here, I provide a Marcusean critique of the spirit and practice of play in the video game industry, specifically in triple-A game production. ${ }^{1}$ Based on my 2.5-year fieldwork in a medium-sized studio (pseudonym: Magic) in the US², I discuss play in relation to a) time and space (flexible work schedule and playful workplace) and $b$ ) video game testing. Regarding the former, I ask: What are the implications when a workplace becomes a playground to which game developers are required to come for only two hours a day? In the latter case regarding video game testing, I revisit the concept of "degradation of fun" (Bulut 2015) and deconstruct the imagination of testing as a 'dream job' where the dream is demystified due to the instrumentalisation and quantification of play, which together lead to the diminishing of pleasure.

In both cases, I engage with Marcuse's concepts of "surplus repression" and "performance principle" and describe industry practices through what I call 'one-dimensional creativity'. Clearly derived from Marcuse's ideological critique of the advanced industrial society, one-dimensional creativity refers mainly to the triple-A game production's conservative production and design principles. These principles are not only heavily structured by profit-maximisation but are also framed primarily by technological virtuosity, materialised in the industry's fetishisation of more realistic graphics and increased interactivity, speed, and machinic performance. In that regard, this article uniquely deploys Marcuse beyond his ideology critique and applies his work to the question of play as it is taken up within video game and creative industry studies.

One-dimensional creativity is a productive concept for several reasons. It demonstrates how the mainstream creativity discourse operates on exclusionary premises, mostly prioritising high-technology machine performance, highly educated populations, and gentrified urban spaces within advanced capitalist countries (Ross 2007). Following from this is the more important intervention that one-dimensional creativity makes. Even critical media scholars have reproduced a somewhat elitist notion of creativity by simply focusing on the Global North (Gibson, Carr and Warren 2015). In that sense, one-dimensional creativity foregrounds the racialised and gendered material infrastructure of video game production along with the everyday creativity, skills, and value of workers in manufacturing regions of the world that produce high-resolution and networked game experiences. So, creativity needs to be democratised beyond the EuroAmerican "genius designer/producer" model fetishised in both trade journals and in educational institutions (Mayer 2011; Mayer, Banks and Caldwell 2009; Banks 2009).

${ }^{1}$ Commonly called the 'blockbusters' of the game industry, triple-A games are high-budget productions created by large teams comprised of hundreds of game developers.

${ }^{2}$ My fieldwork took place in 2010-2013. I engaged in participant observation in a medium-sized game studio and interviewed artists, testers, producers, designers, programmers, human resources staff, and partners of game developers. When I started this project, Magic employed more than 230 employees. As I concluded my ethnography, this number had shrunk to less than 190. I discuss precarious work at Magic elsewhere (Bulut 2015). 
Moreover, in its mainstream definitions limited to cultural industries in the Global North, creativity operates like a conservative doctrine as it imposes performativity and accomplishment and therefore signals a closure (Osborne 2012). We need to liberate creativity from a static moment and an individual accomplishment of invention and novelty and re-associate it with inventiveness as a social and an open-ended egalitarian process (Osborne 2012). As Osborne argues, "inventiveness in art is no doubt rather the repetition of attempt and the elimination of accomplishment" $(2012,296)$. This re-association of creativity with an open-ended inventiveness is also compatible with Raymond Williams's approach to creativity that both democratises creativity and protects it against cultural populism. For Williams, creative work and good art have to "convey an experience to others in such a form that the experience is actively re-created - not contemplated, not examined, not passively received, but by response to the means, actually lived through, by those to whom it is offered" $(1961,51)$.

This critical approach to creativity relates to why Marcuse's work would be valuable for critically understanding video game work. First, in Marcuse's political imagination, the struggle for a just world had to be intersectional and transnational by nature (Forman 2017), and so we need to conceptualise creativity on those terms. Second, to the best of my knowledge, with the exception of Sara Grimes and Andrew Feenberg (2009) and Christian Fuchs's $(2016,128)$ application of Marcuse's theory of play to Facebook, neither creative industry studies nor game studies scholars have considered Marcuse in relation to play and work. Moreover, except for a few scholars (Yee 2006; DyerWitheford and de Peuter 2009; Nakamura 2009; Kerr 2011; Lund 2014), game studies literature still suffers from a fetishism of participation and is still relatively indifferent to the corporatised production dynamics of the industry (Jenkins 2006). Although there has been a sustained engagement with Marcuse in critical theory (Kellner 1984; Wolin 2001; Feenberg 2005), in critical information and media studies (Fuchs 2017), and in social movements studies (Lamas, Wolfson and Funke 2017), engagement with Marcuse's work regarding game production is overdue.

In the remaining sections, I first discuss two key concepts of Marcuse: surplus repression and the performance principle. Next, I examine Magic's attempts to create an affective and flexible workplace in which work and play coalesce, particularly within game testing. I will then discuss these practices in the light of what I call 'one-dimensional creativity'." In my conclusion, I will address alternative understanding and aesthetics of production in relation to queer games, along with the emergence of gaming co-operatives and unionization attempts in the industry.

\section{Herbert Marcuse's Invitation for Play}

Marcuse's work was a critical attempt to address the crisis of Marxism in the 1920s, 1930 s and onwards. The reactionary behaviour of the working classes and an indoctrinated economistic approach towards Marxism forced philosophers like Marcuse to reconstruct Marxist philosophy not as an ideology but "a fallibilistic method of historical understanding" (Wolin 2001, 143).

Two aspects of Marxism's crisis as addressed by Marcuse are of particular concern here. The first concerns scientific Marxism's obsession with controlling nature through technical knowledge. The second concerns the productivist approach towards labour held by certain strands of Marxism. For Marcuse, the value of Marxism was derived not from replicating bourgeois political economy's reified formulations regarding human labour but its ability to recuperate labour as a source of self-realisation. Especially in "On the Philosophical Foundations of the Concept of Labor in Economics", Marcuse (1973) works towards an anthropological definition and moves away from his attempts 
to reconcile Heidegger with Marx. Along the lines of Marx's 1844 Manuscripts, Marcuse argues that it is through labour that "one first becomes 'for oneself' what one is, comes to one's self, acquires the form of one's Dasein, winning one's 'permanence' and at the same time making the world 'one's own'" (Marcuse 1973, 11). However, under capitalism, conditions for practicing free labour are not there yet:

In laboring, the laborer is always 'with the thing': whether one stands by a machine, draws technical plans, is concerned with organizational measures, researches scientific problems, instructs people etc. in his activity, he allows himself to be directed by the thing, subjects himself and obeys its laws, even when he dominates his object, directs it, guides it, and lets it go its own way (Marcuse 1973, 25).

As Richard Wolin $(2001,157)$ insightfully suggests, Marcuse's essay becomes innovative not in relation to labour but play, by way of inspiration from Friedrich Schiller, who wrote: "Man plays only when he is in the full sense of the word a man, and he is only wholly Man when he is playing" (Schiller 1965, 80, quoted in Wolin 2001). Following Schiller, Marcuse constructs the idea of play as the complete opposite of labour, because, when devoid of practical necessities, play could potentially be virtuous:

In play, the objectivity of objects and their effects, and the actuality of the objective world with which one is usually forced constantly to deal, thus learning to respect it, are temporarily suspended. For once, one does entirely as one pleases with objects; one places oneself beyond them and becomes 'free' from them. This is what is decisive: in this self-positing transcendence of objectivity one comes precisely to oneself, in a dimension of freedom denied in labor. In a single toss of a ball, the player achieves an infinitely greater triumph over objectification than in the most powerful accomplishment of technical labor (Wolin 2001, 161; emphasis mine).

Marcuse's engagement with play in this essay lays the groundwork for his future works, especially Eros and Civilization (Marcuse 1998/1955). Eros and Civilization represents Marcuse's attempt to read Freud against Freud in order to rescue the pessimistic reading of the human psyche and to argue that repression is not inevitable. At the centre of Marcuse's critique of Freud - just like his critique of his mentor Heidegger's timeless categories - was the former's historical approach towards society. In Marcuse's thinking, domination of particular groups or repression of instincts were not independent from historical formations and were therefore subject to change. As he argues, "this argument [Freud's argument regarding the dominance of reality principle], which looms large in Freud's metapsychology, is fallacious in so far as it applies to the brute fact of scarcity what actually is the consequence of a specific organization of scarcity, and of a specific existential attitude enforced by this organization" $(1998 / 1955,36)$. The reality principle's continued dominance was not inevitable, especially because the affluent society no longer had to be structured by scarcity thanks to technological advancements. The kind of scarcity underpinning modern economy was artificial, and modern technology had reached such a level that eliminated the need for "surplus repression" and "performance principle," two concepts he coined to historicise domination in Marxian lines.

Curiously, without strictly using Marxian categories, Marcuse defined surplus repression as different from "basic repression", since for Marcuse, there was not just one universal reality principle but "various historical forms of the reality principle" 
$(1998 / 1955,35)$. And under capitalism, a particular form of domination different from the general rationality of authority had emerged. For Marcuse, rationality of authority exists in all societies whereas domination "is exercised by a particular group or individual in order to sustain and enhance itself in a privileged position. Such domination does not exclude technical, material, and intellectual progress, but only as an unavoidable by-product while preserving irrational scarcity, want, and constraint" (Marcuse $1998 / 1955,34)$. It was then the additional forms of control that derived from the specificities of capitalist domination - i.e. wage labour, working day, regimentation of work and leisure etc. - that he called "surplus-repression". The performance principle, on the other hand, was "the prevailing historical form of the reality principle" (1998/1955, 35). It was intrinsically tied to "surplus-repression" and had more to do with the societal compulsion to work, compete, and perform a productive citizenship regarding both production and consumption. Marcuse wrote:

For the vast majority of the population, the scope and mode of satisfaction are determined by their own labor; but their labor is work for an apparatus which they do not control, which operates as an independent power to which individuals must submit if they want to live $(1998 / 1955,45)$.

Clearly proposing a Marxian explanation, Marcuse further suggests that "the basic control of leisure is achieved by the length of the working day itself, by the tiresome and mechanical routine of alienated labor" $(1998 / 1955,47)$. Due to performance principle, even our free time is not completely available for pleasure, leading to the agitation of the pleasure principle. Technology perpetuates the performance principle in that we do not actually need more production or technology to address social problems. It is technology's ontological framework, linked with the performative principle, that produces our problems in the first place.

Therefore, for Marcuse, artistic imagination, phantasy, play, reduction of work time and termination of alienated labour would pave the way for a society based on pleasure. There would still be need for the reality principle to do the necessary work for survival. Nevertheless, the performance principle and surplus repression would be abolished in his conceptualisation of a free society that would be realised through what he called "the Great Refusal", which would produce new forms of subjectivities that were underlined during the 1960s.

In his 1998 preface to Eros and Civilization, Douglas Kellner emphasises how Marcuse's "emphasis on liberation, play, love, and eros anticipated the ethos of the 1960s counterculture" (1998/1955, xi). The 1960s' call for the recovery of the pleasure principle seems to have been turned into joyous labour that fuels the transnational video game industry, an industry worth more than 100 billion dollars in global revenues, excluding hardware and second-hand game sales (Kerr 2017, 2). Is the video game industry, which undermines the strict regimentation of the working day by fusing work with pleasure and play, something of a Marcusean dream realised? On the surface, the answer might be 'yes', but the industry has not completely been able to bring pleasure back to work as imagined by Marcuse. The two moments below - playful space and flexible work environment, playtesting as a form of "playbor" (Kücklich 2009) - will demonstrate how "degradation of fun" (Bulut 2015) is a critical concept to understand and theorise labour practices in the industry, encapsulated by one-dimensional creativity. 


\section{Capitalism's "New Spirit" at Magic: Eroticisation of the Workplace, Revival of Play at Work}

In their work on Post-Fordism's management culture, Luc Boltanski and Ève Chiapello $(2005,8)$ argue that capitalism owes its legitimacy partly to its "spirit", "the ideology that justifies engagement in capitalism". For Boltanski and Chiapello, the spirit of capitalism has to "engage" subjects and make capitalism "attractive." In addition to being engaging, capitalism has to be good at absorbing the criticism of its enemies in order to survive. As they write:

We are going to assign critique the role of a motor in changes in the spirit of capitalism [...] it needs its enemies, people whom it outrages and who are opposed to it, to find the moral supports it lacks and to incorporate mechanisms of justice whose relevance it would otherwise have no reason to acknowledge (2005, 27).

In Boltanski and Chiapello's $(2005,174)$ account, capitalism survived the crisis of Fordism because it managed to absorb the artistic critique of social movements of the 1960 s. This had aimed to replace "the loss of autonomy, the absence of creativity [...] compulsory work schedules, prescribed tasks, the Taylorist separation between design and execution" with "autonomy, self-management, and the promise of an unbounded liberation of human creativity" - a discourse borrowed from "the repertoire of the festival, play". As documented by others (Turner 2009; Ross 2003; Neff, Wissinger and Zukin 2005), creative industries have adopted this formula to 'eroticise' work. And as a creative workplace, Magic is no exception in reviving play at work and aestheticising labour. The management's attempt to eroticise the workplace can be revealed through an analysis of a) the flexible work schedule, and b) the construction and experience of an affective workspace.

Magic's introduction of the 'flexible work environment policy' (FWE) was a response to two problems in the studio: 'crunch' and over-communication. Previous periods of overwork (crunch) had negatively impacted the game developers' well-being. The management also considered holding too many meetings to be an obstacle to productivity. Therefore, the studio initiated a flexible work schedule to alleviate the burden of crunch and reduce communication so that the task of constantly monitoring the workers would be off their checklist.

The actual reason behind FWE, which only required developers to be at the studio for two hours a day and allowed them to do things like jogging during work hours, had more to do with capital's desire to harness the productive capacities of Magic's workforce (Lazzarato 1996). As the management underlined in our conversations:

How do you stick that [creativity] into a 9-5 job, [a] 40-hour [a] week job? It doesn't work in my mind... People have creative moments. They might have them [at] home; they might have them anywhere. We want to keep that. We want to enjoy that. At the same time, we have to also make sure that dependencies and communication happen.

Management's response to the problem of capitalising on creative moments also has a spatial dimension. Magic has specifically been built as an affective workplace to mobilise the emotions of game developers at work. Decidedly different from the cubicle regime, Magic welcomes its workers and visitors as a free and open "playbor" space 
(Kücklich 2009) in order to boost productivity. Comfort, light, and the latest technological equipment abound at Magic. As one walks through the corridors and the kitchen, it is not uncommon to run into developers enjoying adult beverages, free food, discussing work, or at times being involved in nerf-gun fights. Affective design is not simply about making work more enjoyable, though. Play in its pure form also exists at the studio. During lunch or regular work hours, Magic's workers play console games, board games or card games. After all, as one developer said, "it's a place to go and stay all day [...] They [video game producers] want more than the cubicle walls."

Such moments of laughter and pleasure are especially prominent in the work culture of Magic's testers, or quality assurance (QA) workers. Testers provide support for the core development group (designers, artists, programmers). A central mission of testers is to 'debug' games: despite repetitive tasks, they derive an intellectual gratification from this, even though they do not get to 'play' and interact with the core developers as much. Still, despite their second-class status (Bulut 2015; Briziarelli 2016), their labour, derived from their valorised play skills (Charrieras and Roy-Valex 2008), is crucial for our smooth interactive experiences. And although popular imagination regarding game testing is "So, you play games at work", reality is different.

First, testing is serious business. The gigantic scope of triple-A games in terms of code, graphics, and art requires the collaboration of a variety of testers working on different features of games including art, standards and compliance, and multiplayer mode. Second, despite the laid-back workplace culture, the testing department has its own leads and managers who monitor both productivity levels and the attitudes of game testers towards workplace codes. Third, testing is a highly precarious job. The number of full-time positions for testing is limited. Temporary testers are hired when a particular project ramps up and then laid off when they are no longer needed. Precarity is exacerbated due to the large reserve army of testers.

Still, precarity is no obstacle to emotional attachment to the job. A tester (Andy, previously full-time but now temporary) once said to me: "I would take a worse paying and awful job in [the] game development industry over a job having nothing to do with game development". Commitment to precarious testing is sustained mainly in two ways. First, game testing is a symbolically valuable job that allows young people to do an exciting job: playing video games. Second, testers are often passionate gamers who are trained within the ludic regime of interactive consoles. Not only is play a pedagogical and embodied terrain for cultivating ardent player-workers (Yee 2006; DyerWitheford and de Peuter 2009) but also a very productive skill (Charrieras and RoyValex 2008) to possess as a tester. Drawing on Lund (2014) and Fuchs's (2014, 122127) discussion of the relationship between ideology and the practice of participatory play, it becomes evident that play has turned into labour under the logic of commodity production. Thus, the question becomes: How can we critically understand the revival of work where even the studio's most precarious citizens still desire a wage relationship with the real owners of intellectual property? What critical lexicon, if any, can we deploy through Marcuse?

\section{Instrumentalisation of Pleasure, Degradation of Fun, and One-Dimensional Creativity}

Building on the game industry's historical tendency to fuse work and pleasure, Magic has eroticised the workplace. By introducing elements of freedom, flexibility, and openness, it has successfully instrumentalised the pleasure principle for surplus value creation. As opposed to Marcuse's advanced industrial society in which search for pleasure had to be limited to spare time, pleasure defines the essence of Magic. Developers 
are invited to enjoy work. Magic's workers are no longer required to repress pleasure but rather to perpetually cultivate it in the workplace and capitalise on it. The reality principle no longer sublates the pleasure principle. Rather, the pleasure principle has almost become the universal sign at Magic. In sum, Eros in the game industry is not destructive. It is productive and that is why it is valuable.

At Magic, the pleasure principle seems to be unleashed through a trust-based relationship, but in reality a gift-giving practice between the management and Magic's workers is taking place. The gift from the management is freedom, but neither freedom nor pleasure is free. Something is regarded as a gift only when it is not named as such and is beyond reciprocity (Walker 2011). The gift exchange at Magic, however, is mediated through wage labour. The affective spatiality and flexible temporality at Magic is not an unrestrained form of unleashing creative pleasures and free play. Rather, cultivation of creativity and openness depends strictly on responsible developers' ability to deliver. Openness and collaboration are good only insofar as they conform to a particular regime of accumulation. The pleasure principle is unleashed only to the extent that the reality principle of value creation is ensured. In that regard, the abundant freedom and Magic's celebration of flexible creativity is an administered form of gift (Walker 2011, 370). After all, the management has underlined how they "have to also make sure that dependencies and communication happen" in relation to the FWE.

That reveals the dichotomy at the heart of Magic. The dreams of open creativity from the 1960s define the soul of the video game industry. Could such creativity and openness actually represent the one-dimensionality of our times? What does it mean that almost every creative workplace claims difference and uniqueness by adhering to fairly similar recipes of horizontality in order to achieve productivity?

"If the one-dimensional man of the 1950 s believed all was well, the $21^{\text {st }}$ century one-dimensional man and woman believe there is no alternative to the privatization of everything," writes Michael Forman $(2017,37)$ in his discussion of how Marcuse's theorisation has remained mostly relevant despite global political-economic changes. Along this argument, I suggest extending Marcuse's critique of the advanced industrial society - one-dimensionality - to conceptualise $21^{\text {st }}$ century work practices in the game industry. As opposed to industrial labour or cubicle-office work, conformity in the game industry is ensured not through hierarchical repression but through openness and a regime of one-dimensional creativity. Such one-dimensional creativity superficially eliminates the reality principle in the name of the pleasure principle, but creativity only counts if it is economically viable. Despite claims of openness and horizontality, this one-dimensional creativity is still framed by a technological rationality, "a form of rationality that grasps its objects on purely functional terms without presupposing any goal except its own application and extension" (Feenberg 2017, 232).

When one examines the workplace and the labour process at Magic, the reality principle seems to be eliminated but the pleasure principle is exalted only for more 'realistic' graphics or profit maximisation. Although the labour process at Magic is far from a 'totally administered' one, it is still a highly administered one as it is subject to market rules, the dictates of the console cycles, and the dynamics of perpetual innovation (Nieborg 2014). The kind of creativity fetishised at Magic is a reified one that restrains aesthetics to economic value and technological performance.

One-dimensional creativity has also implications in relation to time. While the dream of the 1960s was to maximise free time, Magic makes working time flexible to the extent that work becomes endless (Gregg 2011). Pleasure seems to rule but the reality principle and self-control are never dead. As one developer explained the difficulties he faced in adjusting to FWE: "it required me to exercise more self-control because I 
technically didn't have to get into work until 3pm." The supposedly overthrown technological rationality comes back through what Gilles Deleuze (1992) called "societies of control" in which profit maximisation is only rendered more playful and less bureaucratic. Less bureaucracy, however, does not mean that pleasure derived from playful creativity is experienced equally across different sections of the workforce. That is, the testers have less space and time to enjoy pleasure than the core creatives such as programmers, designers, artists. Testers painfully experience instrumentalisation of play through "degradation of fun" (Bulut 2015), which renders the "coolness" of game development less tenable (McGuigan 2012).

"Degradation of fun" is inspired by labour scholar Harry Braverman's (1998/1974) notion of "degradation of labor," which demonstrates how white-collar office work is not immune from micro-managing, leading ultimately to the "deskilling of laborers through machinery and managerial control" (Braverman 1998/1974, 48). "Degradation of fun" is also inspired by Frankfurt School theorists (Adorno and Horkheimer 2010/1944) for whom culture is nothing other than mass-produced commodities that reproduce the status quo. In sum, "degradation of fun" refers to how the joy of video game testing is diminished because play becomes instrumentalised through time discipline and specific tasks. Apart from very obvious reasons, such as precarity and long working hours, "degradation of fun" takes place due mainly to two interlinked reasons: instrumentalisation and quantification of play.

First, as opposed to free play, play within game testing is instrumentalised and subject to tasks that need to be completed during a certain period of time. Even though game testers look like they are just playing video games, they need to "put what [they] are doing in words", or else they are "just playing", a tester told me. Instrumentalisation of play also leaks beyond the workplace in that testers start playing games in order to improve their employability and catch up with the industry. Play for play's sake is over.

Second, play in the industry is measured and surveilled. Specifically, the number of bugs one can detect during testing is quantified through software. Testers are expected to find a certain amount of bugs in a game depending on the status of the project. Quantification is also possible through play in that fellow testers compete against each other to see who finds more bugs at the end of the workday. So despite its seemingly evasive and playful nature, the kind of (im)material labour that game testing involves is measurable (Hearn 2010; Dowling 2007).

What does degradation of fun look like if play becomes instrumentalised and quantified? As they told me during my fieldwork, some game-testers don't "even want to look at a computer screen", whereas others feel that the biggest downside is that it "changes the way you play video games". The job of play-testing turns testers into game critics where they find themselves criticising the games rather than simply enjoying them. Playing video games outside work becomes a lot harder. Despite its potentials to be a remedy to disenchantment at work, play becomes a source of leisurely disenchantment when it becomes work-like. Quantification destroys play's magical qualities.

As Caroline Edwards $(2013,1)$ suggests, part of Marcuse's struggle in Eros and Civilization is focused on "the temporal dialectic between alienated labor time and the timelessness of pleasure's desire for eternity" and Marcuse's utopian project was partly to maximise time for pleasure, as he defined labour time as painful time. In the case of Magic's testers, free time, too, becomes somewhat painful since gratification from play during free time diminishes. How a tester passes time outside work through play is fundamentally transformed. Restrictions on Eros at work are lifted, but this somewhat kills Eros outside the workplace. 
Is play, in its degraded, instrumentalised, and quantified form, still play? According to Marcuse $(1998 / 1955,187)$ "the play impulse does not aim at playing 'with' something; rather it is the play of life itself, beyond want and external compulsion - the manifestation of an existence without fear and anxiety, and thus the manifestation of freedom itself". For the play element in game testing to be completely free, the necessity for "external compulsion" has to be eliminated. The answer is not different for theorists of play, either. Despite some differences, major theorists of play have mostly agreed on the definition of play as free and voluntary activity. Huizinga (1944, 13), for instance, defined play as "a free activity standing quite consciously outside 'ordinary' life as being 'not serious', but at the same time absorbing the player intensely and utterly. It is an activity connected with no material interest, and no profit can be gained by it". On similar terms, Roger Caillois wrote that "A game which one would be forced to play would at once cease being play", adding that players should be "free to leave whenever they please, by saying: "I'm not playing anymore" $(1961,6)$. Undoubtedly, neoliberal economics suggests that testers freely choose to be employed and they can stop playing/working any time. But if one's survival depends on wage labour, can we really talk about the freedom to quit?

Nonetheless, despite the drawbacks, game testing still comes very close to the affirmation of the self and the play-like features of testing as a job reveal the "de-alienating" sides of it (Fisher 2012). If it weren't for these de-alienating aspects, it would be hard to understand testers' desire to want a worse job in the game industry than a better job in other sectors. The work of testers is not only compensated by money but also by the very embodied pleasures they derive from work, which are integrated into the very fabric of the self of the game tester. Indeed, since game testing has play features in it, the performance principle, with its ludic elements, may become harder to disrupt or resist.

\section{Conclusion: Where are the Multi-Dimensional Games?}

The major players in the triple-A business are all financialised entities. This financialised political economic structure forces developers to produce sequel games within the limitations of the dominant genres. What matters is not a diversity of narratives, stories, or aesthetics, but technological power driven by intense competition. Despite the industry's technological jump since the 1960s, the genres, narratives, and aesthetics dominating the triple-A industry give us a "risk adverse, conservative design" (Keogh $2015,153)$ production logic, which I have conceptualised through 'one-dimensional creativity'.

With its instrumental approach towards play, the hegemonic one-dimensionality in the industry fails to transcend existing genres and design structures precisely because it is fixated on technological virtuosity tied to the performance principle. As Leigh Alexander $(2017 / 2013,58)$ suggests, "game companies bet on becoming the single most attractive player in the same homogenous field rather than branching out to create something new and risking expensive failure". In One-Dimensional Man, Marcuse $(1964,11)$ wrote: "People recognize themselves in their commodities. They find their soul in their automobile, hi-fi set, split-level home, kitchen equipment". Today, we find our souls in our smartphones and game consoles. It seems that the creative souls in the triple-A industry are strictly defined by the technical objectivity of speed, performance, and screen resolution. Certainly, a tech-driven creativity does give individuals the opportunity to express themselves but it negates genuine authorship and different kinds of creativities that could have emerged if it weren't for the one-dimensional creativity that has colonised the majority of triple-A business. Therefore, it is unlikely that 
forms and practices of multi-dimensional creativity and such games will come from the triple-A production scene.

Perhaps it will be DIY and amateur game-makers that will redefine creativity in multi-dimensional and dialectical ways. Game-maker populations at the margins of a predominantly heterosexual-white-male production world are already challenging the one-dimensional creativity structuring game production and imagination. This is possible thanks not only to lower levels of entry to game creation and new technological tools such as Twine but also amateur game-makers' transformative and critical approach towards art and culture. For instance, on the one hand, games like Cart Life critically address neoliberalism's socio-economic destruction. On the other hand, the production and analysis of video games through a queer lens have opened new venues for re-imagining play, disrupting rules, rethinking assumptions, and challenging dominant aesthetic forms and representation (Ruberg and Shaw 2017). Dys4ia, for instance, reveals the intimate struggles as one goes through gender transition. The game's creator Anna Anthropy (2012) makes a call for people to produce a video game as if sketching a poem in order to raise a critique of a social issue, without being obsessed with performance. The initiative of these designers and scholars are far from reproducing the one-dimensional logic in the triple-A business, or what we previously called logics of "philitainment" in the case of a politically flawed neoliberal serious games movement (Bulut, Mejia and McCarthy 2014).

What is heartening about the queer games movement is not simply the inclusion of different bodies in games but the opening of game production to people of colour and non-conforming bodies and identities. Somewhat echoing Adorno, these games also defy the hegemonic understanding of what counts as fun. In that regard, the emergence of counter-models of creativity that challenge one-dimensional creativity is promising, since marginalised bodies and minds become authors and designers of non-conforming narratives, genres, and aesthetics that disrupt the one-dimensional creativity in the broader game industry.

In addition to aesthetics, there are other practices challenging the hegemonic tripleA logics in terms of both production and consumption. First, there is the broader phenomenon of emerging technology co-ops that aim to democratise production (Van Slyke 2013). The politics of these technology co-op practices is similar to ambivalent co-working spaces (de Peuter, Cohen and Saraco 2017) but less progressive than the emerging workers' co-operatives resisting precarious work (Sandoval 2016). For instance, on the one hand, there are the more neoliberally-minded organisations, such as the Atlanta Game Cooperative, that aim to match game talent needing supplemental income with game companies in search of skilled game workers. On the other hand, initiatives like St. Louis Game Developer Co-op organises "game jams, educational seminars, demo and playtesting events, microtalks, roundtables, workshops, networking events" (http://stlgamedev.com/) and aim to cultivate a collaborative, respectful, and diverse work environment. Somewhat resembling a combination of the Atlanta and the St. Louis model, Quebec's Guild of Video Game Developers' mission is to create a sustainable business environment for established companies and to support emerging independent game developers. The Guild offers diverse services ranging from networking events, accounting, insurance, legal services, group health insurance and mentoring (http://www.laguilde.quebec/en/member-services/). Overall, these game coops are far from constructing an anti-capitalist production ecology, but still present venues for workers to have alternative conversations and engage in practices different from the triple-A scene. 
Perhaps more promising than the video game co-ops is the contested terrain of independent game ecology providing different models of production (Pedercini 2012; Ruffino 2013; Lipkin 2013). More game developers are leaving the triple-A world to make their own games and form networks based on individual empowerment. However, workers' autonomy is still hard to achieve since corporate platforms such as Xbox Live, Playstation network, and Steam dominate distribution networks and expropriate workers' precarious labour.

As a response, different channels of independent game distribution such as itch.io are emerging. Similarly, consumers' reaction to the one-dimensional aesthetics of triple-A games have produced alternative crowdfunding models, transforming consumers into "prosumer-investors" (Plannells 2017; Tyni 2017). Whether such models present anti-capitalist models of work, consumption, or distribution is contested but they do raise entry points through which hegemonic modes of production and aesthetics can be targeted.

Finally, during the 2018 Game Developers Conference (GDC), game developers debated the implications of unionisation. A week prior to GDC, an organisation called Game Workers Unite emerged. Game Workers Unite was active throughout GDC and distributed pamphlets and zines to inform game developers about the potential benefits of unionisation. Through this organisation, activist game developers are now trying to "connect pro-union activists, exploited workers, and allies across borders and across ideologies in the name of building a unionized game industry" (https://www.gameworkersunite.org/about-us). Who knows? Perhaps in the near future, we will witness a video game labour movement that will radically challenge the logics of one-dimensional creativity in the industry.

\section{References}

Adorno, Theodor and Max Horkheimer. 2010/1944. "The Culture Industry: Enlightenment as Mass Deception." In Cultural Theory: An Anthology, edited by Imre Szeman and Timothy Kaposy, 40-53. Chicester: Wiley-Blackwell.

Alexander, Leigh. 2017/2013. Playing Outside. In Queer Game Studies, edited by Bonnie Ruberg and Adrienne Shaw, 55-63. Minneapolis: University of Minnesota Press.

Anthropy, Anna. 2012. Rise of Videogame Zinesters. New York: Seven Stories Press.

Banks, Miranda. 2009. Gender Below-the-Line: Defining Feminist Production Studies. In Production Studies: Cultural Studies of Media Industries, edited by Vicki Mayer, Miranda Banks and John Thornton Caldwell, 87-99. New York: Routledge.

Boltanski, Luc and Eve Chiapello. 2005. The New Spirit of Capitalism. London: Verso.

Braverman, Harry. 1998/1974. Labor and Monopoly Capital; the Degradation of Work in the Twentieth Century. New York: Monthly Review Press.

Briziarelli, Marco. 2016. Invisible Play and Invisible Game: Video Game Testers or The Unsung Heroes of Knowledge Working. tripleC: Communication, Capitalism \& Critique 14 (1): 249-259.

Bulut, Ergin. 2015. Playboring in the Tester Pit: The Convergence of Precarity and the Degradation of Fun in Video Game Testing. Television \& New Media 16 (3): 240-58.

Bulut, Ergin, Robert Mejia and Cameron McCarthy. 2014. Governance through Philitainment: Playing the Benevolent Subject. Communication and Critical/Cultural Studies. 11 (4):342361.

Caillois, Roger. 1961. Man, Play, and Games. New York: Free Press of Glencoe.

Charrieras, Damien and Myrtille Roy-Valex. 2008. "Video Game Culture as Popular Culture? The Productive Leisure of Video Game Workers of Montreal." Paper presented in the annual meeting of the International Communication Association, Canada. 
De Peuter, Greig, Nicole Cohen and Francesca Saraco. 2017. The ambivalence of coworking: On the politics of an emerging work practice. European Journal of Cultural Studies 20 (6): 687-706. Doi: 10.1177/1367549417732997

Deleuze, Gilles. 1992. Postscript on the Societies of Control. October 59 (Winter): 3-7.

Dowling, Emma. 2007. Producing the Dining Experience: Measure, Subjectivity and the Affective Worker. Ephemera 7 (1): 117-32.

Dyer-Witheford, Nick and Greig de Peuter. 2009. Games of Empire: Global Capitalism and Video Games. Minneapolis: University of Minnesota Press.

Edwards, Caroline. 2013. From Eros to Eschaton: Herbert Marcuse's Liberation of Time. Telos Winter 2013 (165): 91-114.

Feenberg, Andrew. 2017. Beyond One-Dimensionality. In The Great Refusal: Herbert Marcuse and Contemporary Social Movements, edited by Andrew Lamas, Todd Wolfson and Peter Funke, 229-41. Philadelphia: Temple University Press.

Feenberg, Andrew. 2005. Heidegger and Marcuse: The Catastrophe and Redemption of History. New York: Routledge.

Fisher, Eran. 2012. How Less Alienation Creates More Exploitation? Audience Labour on Social Network Sites. tripleC: Communication, Capitalism \& Critique. Open Access Journal for a Global Sustainable Information Society 10 (2): 171-83.

Forman, Michael. 2017. Marcuse in the Crisis of Neoliberal Capitalism. In The Great Refusal: Herbert Marcuse and Contemporary Social Movements, edited by Andrew Lamas, Todd Wolfson and Peter Funke, 29-54. Philadelphia: Temple University Press.

Fuchs, Christian 2017. Herbert Marcuse and the Dialectics of Social Media. In The Great Refusal: Herbert Marcuse and Contemporary Social Movements, edited by Andrew Lamas, Todd Wolfson and Peter Funke, 241-57. Philadelphia: Temple University Press.

Fuchs, Christian. 2016. Critical Theory of Communication: New Readings of Lukács, Adorno, Marcuse, Honneth and Habermas in the Age of the Internet. London: Westminster University Press.

Fuchs, Christian. 2014. Digital Labor and Karl Marx. London: Routledge.

Funke, Peter, Andrew Lamas and Todd Wolfson. 2017. Bouazizi's Refusal and Ours: Critical Reflections on the Great Refusal and Contemporary Social Movements. In The Great Refusal: Herbert Marcuse and Contemporary Social Movements, edited by Andrew Lamas, Todd Wolfson and Peter Funke, 1-25. Philadelphia: Temple University Press.

Gibson, Chris, Chantel Carr and Andrew Warren. 2015. Making Things: Beyond the Binary of Manufacturing and Creativity. In The Routledge Companion to the Cultural Industries, edited by Kate Oakley and Justin O'Connor, 86-96. New York: Routledge.

Gregg, Melissa. 2011. Work's Intimacy. Cambridge: Polity Press.

Grimes, Sara M. and Andrew Feenberg. 2009. Rationalizing Play: A Critical Theory of Digital Gaming. The Information Society 25 (2): 105-18.

Hearn, Alison. 2010. Reality Television, The Hills, and the Limits of the Immaterial Labour Thesis. tripleC: Communication, Capitalism \& Critique 8 (1): 60-76.

Huizinga, Johan. 1944. Homo Ludens; a Study of the Play-Element in Culture. London: Routledge \& Kegan Paul.

Jenkins, Henry. 2006. Fans, Bloggers, and Gamers: Exploring Participatory Culture. New York: NYU Press.

Kellner, Douglas. 1984. Herbert Marcuse and the Crisis of Marxism. Berkeley: University of California Press.

Keogh, Brendan. 2015. Between Triple-A, Indie, Casual, and DIY: Sites of Tension in the Videogames Cultural Industries. In Routledge Companion to the Cultural Industries, edited by Justin O'Connor and Kate Oakley, 152-62. New York: Routledge.

Kerr, Aphra. 2017. Global Games: Production, Circulation and Policy in the Networked Era. New York: Routledge.

Kerr, Aphra. 2011. The Culture of Gamework. In Managing Media Work, edited by Mark Deuze, 225-37. Thousand Oaks: SAGE Publications. 
Kücklich, Julian. 2009. Virtual Worlds and Their Discontents: Precarious Sovereignty, Governmentality, and the Ideology of Play. Games and Culture 4 (4): 340-52.

Lamas, Andrew, Todd Wolfson and Peter Funke, eds. 2017. The Great Refusal: Herbert Marcuse and Contemporary Social Movements. Philadelphia: Temple University Press.

Lazzarato, Maurizio. 1996. Immaterial Labor. In Radical Thought in Italy, edited by Paolo Virno and Michael Hardt, 133-51. Minneapolis: University of Minnesota Press.

Lipkin, Nadav. 2013. Examining Indie's Independence: The Meaning of "Indie" Games, the Politics of Production, and Mainstream Cooptation. Loading... 7 (11): 8-24.

Lund, Arwid. 2014. Playing, Gaming, Working and Labouring: Framing the Concepts and Relations. tripleC: Communication, Capitalism \& Critique 12 (2): 735-801.

Marcuse, Herbert. 2007. The Affirmative Character of Culture. In Art and Liberation: Collected Papers of Herbert Marcuse Volume Four, edited by Douglas Kellner, 82-113. New York: Routledge.

Marcuse, Herbert. 1998/1955. Eros and Civilization: A Philosophical Inquiry into Freud. Humanitas; Beacon Studies in Humanities. Boston: Beacon Press.

Marcuse, Herbert. 1973. On the Philosophical Foundation of the Concept of Labor in Economics. Telos Summer (16): 9-37.

Marcuse, Herbert. 1964. One-Dimensional Man [2nd edition]. Boston: Routledge \& Kegan Paul.

Mayer, Vicki. 2011. Below the Line: Producers and Production Studies in the New Television Economy. Durham, NC: Duke University Press.

Mayer, Vicki, Miranda Banks and John Thornton Caldwell, eds. 2009. Production Studies: Cultural Studies of Media Industries. New York: Routledge.

McGuigan, Jim. 2012. The Coolness of Capitalism Today. tripleC: Communication, Capitalism \& Critique 10 (2): 425-38.

Miller, Patrick and Brad Bulkley. 2013. Game Developer Quality-of-Life Survey. Gamasutra, March.

Nakamura, Lisa. 2009. Don't Hate the Player, Hate the Game: The Racialization of Labor in World of Warcraft. Critical Studies in Media Communication 26 (2): 128-44.

Neff, Gina, Elizabeth Wissinger and Sharon Zukin. 2005. Entrepreneurial Labor among Cultural Producers: 'Cool' Jobs in 'Hot' Industries. Social Semiotics 15 (3): 307-34.

Nieborg, David. 2014. Prolonging the Magic: The Political Economy of the $7^{\text {th }}$ Generation Console Game. Eludamos: Journal for Computer Game Culture. 8 (1): 47-63.

Osborne, Thomas. 2012. Against 'Creativity': A Philistine Rant. In Creative Industries: Critical Readings Volume 1: Concepts, edited by Brian Mocran and Ana Alacovska, 282-300. London: Bloomsbury.

Pedercini, Paolo. 2012. Toward Independence. Talk, Indiecade 2012. Accessed 14 May 2018. http://www.molleindustria.org/blog/toward-independence-indiecade-2012-microtalk/

Plannells, Antonio Jose. 2017. Video games and the crowdfunding ideology: From the gamer-buyer to the prosumer-investor. Journal of Consumer Culture 17 (3): 620-638.

Rey, PJ. 2015. Gamification and Post-Fordist Capitalism. In The Gameful Word: Approaches, Issues, Applications, edited by Steffen Walz and Sebastian Deterding, 277-295. Massachusetts: MIT Press.

Ross, Andrew. 2007. Nice Work If You Can Get It: The Mercurial Career of Creative Industries Policy. In My Creativity Reader, edited by Geert Lovink and Ned Rossiter, 17-41. Amster: Institute of Network Cultures.

Ross, Andrew. 2003. No-Collar: The Humane Workplace and Its Hidden Costs. Philadelphia: Temple University Press.

Ruberg, Bonnie and Adrienne Shaw. 2017. Queer Game Studies. Minneapolis: University of Minnesota Press.

Ruffino, Paolo. 2013. Narratives of independent production in video game culture. Loading... 7 (11): 106-121. 
Sandoval, Marisol. 2016. Fighting Precarity with Co-operation? Worker Co-Operatives in the Cultural Sector. New Formations 88: 51-68.

Schiller, Friedrich. 1965. On the Aesthetic Education of Man: A Series of Letters. New York: Frederick Ungar.

Tokumitsu, Miya. 2015. Do What You Love: And Other Lies About Success and Happiness. New York: Regan Arts.

Turner, Fred. 2009. Burning Man at Google: A Cultural Infrastructure for New Media Production. New Media \& Society 11 (1-2): 73-94.

Tyni, Heikki. 2017. Double Duty: Crowdfunding and the Evolving Game Production Network. Games and Culture. 1-24. Doi: 10.1177/1555412017748108.

Van Slyke, Brian. 2013. The Argument for Worker-Owned Tech Collectives. Fast Company. Accessed June 1, 2018. https://www.fastcompany.com/3021964/the-argument-for-workerowned-tech-collectives

Walker, Abe. 2011. 'Creativity Loves Constraints': The Paradox of Google's Twenty Percent Time. Ephemera 11 (4): 369-87.

Williams, Raymond. 1961. The Long Revolution. Harmondsworth: Penguin.

Wolin, Richard. 2001. Heidegger's Children: Hannah Arendt, Karl Lowith, Hans Jonas, and Herbert Marcuse. Princeton: Princeton University Press.

Yee, Nick. 2006. The Labor of Fun: How Video Games Blur the Boundaries of Work and Play. Games and Culture 1 (1): 68-71.

\section{About the Author}

Ergin Bulut

Ergin Bulut works as an assistant professor in the Department of Media and Visual Arts at Koç University, Istanbul. His work and teaching engages with creative industries and creative labour, political economy of video games within a global context, digital media and politics, and global media. His research has been published in peer-reviewed journals including International Journal of Communication, Media, Culture and Society, Journal of Communication Inquiry, Critical Studies in Media Communication, Television and New Media, Communication and Critical/Cultural Studies, Interactions: Studies in Communication and Culture, Review of Education, Pedagogy, and Cultural Studies, Globalization, Societies and Education. He is currently finishing his book, tentatively titled A Precarious Game: Labor of Love in the Digital Game Industry. 